\title{
PENERAPAN MODEL PEMBELAJARAN KOOPERATIF MIND MAPPING BERBASIS MEDIA AUDIO VISUAL PADA MATERI KUBUS DAN BALOK
}

\author{
Ana Istiani ${ }^{1}$, Siti Rahayu ${ }^{2}$ \\ ${ }^{1,2}$ Program Studi Pendidikan Matematika, STKIP Muhammadiyah Pringsewu Lampung \\ Email : ${ }^{1}$ anaistiani@ stkipmpringsewu-lpg.ac.id \\ ${ }^{2}$ rahayu@stkipmpringsewu-lpg.ac.id
}

\begin{abstract}
The purpose of this research was to know: (1) there is difference of mean of result of student's mathematics learning on cube and block material whose learning apply cooperative mind mapping model based on audio visual media and without audio visual media, (2) average result learning mathematics of students on the material of cubes and blocks learning to apply cooperative learning model mind mapping based audio visual media greater than the average learning outcomes of students learning mathematics applying cooperative mind mapping learning model. The population in this study were VIII class students even semester SMP Negeri 1 Sukoharjo academic year 2015-2016, sampling using sampling technique and obtained samples of two classes. This study involves only one variable that is the result of learning mathematics in cube and beam material, consisting of two samples that is the result of learning mathematics of students whose learning applying cooperative learning model mind mapping based on audio visual media as sample 1 and the result of learning mathematics of students whose learning apply cooperative learning model mind mapping as sample 2 obtained through the test of mathematics learning result given to sample 1 and sample 2 in the form of description test. Technique of data analysis using quantitative data analysis covering data normality test stage, homogeneity test, $t$ test, $U$ test one side, conclusion. Based on the results of research concluded that there are differences in the average results of students' mathematics learning on cube and beam material that learning applying cooperative learning model mind mapping based audio visual media and without audio visual media. The average of students' mathematics learning outcomes on cube and beam materials whose learning is to apply cooperative mind mapping model based on audio visual media is greater than the average of mathematics learning outcomes of students whose learning applied cooperative mind mapping model. This is due to mind mapping cooperative learning based on audio visual media provides an opportunity for students to be more active and students become more motivated in the learning process that lures students become more imaginative and creative in developing the potential work of the brain and mindset so that students can think actively, critical, full of ideas, and easy to organize and remember all forms of information conveyed by the teacher.
\end{abstract}

Keywords: learning mathematics, cooperative, mind mapping, audio visual media 


\section{A. PENDAHULUAN}

Perkembangan ilmu pengetahuan dan teknologi, khususnya teknologi informasi sekarang ini telah memberikan dampak positif dalam semua aspek kehidupan manusia termasuk juga aspek pendidikan. Pendidikan merupakan masalah yang menarik untuk dibahas, karena melalui usaha pendidikan diharapkan tujuan pendidikan akan dapat tercapai. Untuk mencapai tujuan pendidikan, maka proses pembelajaran yang dilakukan oleh guru juga harus sesuai dengan standar proses pendidikan. Proses pembelajaran hendaknya terjadi interaksi atau hubungan timbal balik antara siswa dengan guru, proses pembelajaran dapat memberikan inspirasi bagi siswa maupun guru untuk dapat belajar lebih baik lagi, suasana pembelajaran yang menyenangkan serta menantang siswa untuk berpikir kritis serta dapat mengembangkan ide-idenya tentang materi pembelajaran yang diajarkan oleh guru. Selain itu dalam proses pembelajaran guru harus dapat memberikan ruang yang cukup bagi prakarsa, kreativitas, serta kemandirian sesuai bakat, minat, dan perkembangan psikologis siswa. Guru diharapkan dapat kreatif dalam memanfaatkan sumber belajar, model pembelajaran, maupun media dalam proses pembelajaran serta memberikan kesempatan kepada siswa untuk mengembangkan pola pikirnya secara kreatif sehingga siswa dapat menyelesaikan masalah sendiri secara mandiri sesuai kemampuan siswa sebelum guru memberikan penjelasan tentang penyelesaian masalah tersebut.

Mengingat peranan matematika yang sangat besar dalam perkembangan ilmu pengetahuan dan teknologi (IPTEK), usaha peningkatan kualitas pendidikan matematika masih menghadapi berbagai permasalahan, diantaranya masih banyak konsep dalam matematika yang belum dikuasai siswa, hal ini dikarenakan dalam proses pembelajaran matematika para siswa diharuskan untuk menghafalkan rumusrumus matematika yang sangat banyak dan menghitung angka-angka yang rumit. Padahal dengan menghafal siswa akan sulit untuk dapat menguasai konsep matematika. Sehingga matematika dipandang sebagai mata pelajaran yang menakutkan dan membosankan. Akibatnya berpengaruh terhadap sikap siswa yang kurang antusias terhadap mata pelajaran matematika. Konsep matematika akan mudah ditanamkan pada diri siswa jika dalam proses pembelajaran matematika guru memberikan kesempatan agar siswa dapat mengembangkan pola pikirannya sendiri dalam pembelajaran, guru juga harus dapat menciptakan suasana belajar yang nyaman dan menyenangkan. Model pembelajaran yang variatif dan menyediakan banyak pilihan belajar memungkinkan ber- 
kembangnya potensi peserta didik. Dengan demikian peserta didik diberi kesempatan berkembang sesuai dengan kapasitas, gaya belajar, maupun pengalaman belajarnya. (Murtiyasa, n.d.).

Model pembelajaran kooperatif merupakan salah satu model pembelajaran yang dapat menciptakan suasana belajar lebih menyenangkan. Sanjaya (2010:241) mengemukakan "model pembelajaran kooperatif adalah serangkaian kegiatan belajar yang dilakukan siswa dalam kelompokkelompok tertentu untuk mencapai tujuan pembelajaran yang telah dirumuskan".

Pembelajaran matematika di SMP Negeri 1 Sukoharjo pada materi kubus dan balok, guru sudah menerapkan model pembelajaran kooperatif yang berupa teknik mencatat yang kreatif yaitu mind mapping. Pembelajaran kooperatif mind mapping adalah cara kreatif bagi peserta didik secara individual untuk menghasilkan ide-ide, mencatat pelajaran, atau merencanakan penelitian baru (Silberman (2009:188). Selain itu cara ini juga menenangkan, menyenangkan dan kreatif. Hal ini sesuai dengan pendapat Zampetakis dan Tsironis (2007) yang mengatakan bahwa mind mapping adalah alat yang bahkan dapat membuat tugas yang membosankan menjadi yang paling menyenangkan dan menarik, sehingga dapat meningkatkan konsentrasi dan daya ingat.(Kreativitas, Dalam, \& Ekonomi, 2015).
Namun penggunaan model pembelajaran tersebut masih kurang optimal, hal ini bisa saja disebabkan karena guru memiliki banyak faktor kendala antara lain: keterbatasan waktu dalam pembelajaran, kelelahan karena mengajar beberapa jam sehari, serta terkadang guru enggan untuk mengulang materi yang sama di kelas tertentu. Selain itu kelemahan-kelemahan yang ada pada model pembelajaran kooperatif mind mapping ini yaitu antara lain hanya siswa aktif yang terlibat; tidak sepenuhnya murid yang belajar; mind map siswa bervariasi sehingga guru akan kewalahan memeriksa mind map siswa. Alokasi waktu dalam pembelajaran juga mempengaruhi kurang optimalnya penerapan model pembelajaran kooperatif mind mapping. Proses pembuatan mind mapping dalam pembelajaran kooperatif akan membutuhkan waktu yang banyak, karena siswa diberikan kebebasan oleh guru untuk mengembangkan pola pikirnya. Selain itu dalam penyampaian materi pembelajaran, guru masih menyampaikan materi secara lisan, sehingga siswa kurang tertarik dan tidak fokus memperhatikan materi yang disampaikan oleh guru.

Solusi dari permasalahan tersebut adalah memodifikasi model pembelajaran kooperatif mind mapping dengan menggunakan media audio visiual. Dengan penggunaan media audio visual ini diharapkan dapat menciptakan suasana belajar 
yang nyaman, menyenangkan serta dapat mengefisiensikan waktu. Media audio visual adalah media yang mempunyai unsur suara dan unsur gambar. Dalam proses pembelajaran siswa akan belajar dengan mendengar dan melihat materi untuk kemudian siswa akan mengembangkan pola pikirnya sendiri tentang materi tersebut sesuai dengan kreatifitas masing-masing.

Metode pembelajaran mind mapping adalah sistem penyimpanan, penarikan data, dan akses yang luar biasa untuk perpustakaan raksasa, yang sebenarnya ada dalam otak manusia yang menakjubkan (Buzan, 2010:12). Selain itu, mind mapping menurut Buzan (2010:4) adalah cara termudah untuk menempatkan informasi ke dalam otak dan mengambil formasi ke luar dari otak mind mapping adalah cara mencatat kreatif, efektif, dan secara harfiah "memetakan" pikiran-pikiran kita. Dengan mind mapping daftar informasi yang panjang bisa dialihkan menjadi diagram warna-warni, sangat teratur, dan mudah diingat yang bekerja selaras dengan cara kerja otak dalam melakukan berbagai hal.

\section{B. METODE PENELITIAN}

Variabel dalam penelitian ini adalah hasil belajar matematika siswa kelas VIII semester genap SMP N 1 Sukoharjo tahun pelajaran 2015-2016 pada materi kubus dan balok, yang terdiri dari dua sampel yaitu hasil belajar matematika siswa yang pembelajarannya menerapkan model pembelajaran kooperatif mind mapping berbasis media audio visual sebagai sampel 1 dan hasil belajar matematika siswa yang pembelajarannya menerapkan model pembelajaran kooperatif mind mapping sebagai sampel 2. Yang dimaksud hasil belajar matematika adalah hasil yang diperoleh siswa setelah ia menerima suatu pengetahuan yang berupa angka (nilai), nilai kemampuan yang diperoleh siswa dari skor melalui interaksi tindakan belajar dan mengajar. Variabel hasil belajar matematika siswa diperoleh melalui tes hasil belajar matematika yang diberikan kepada sampel 1 dan sampel 2 yang berbentuk tes uraian dengan tingkat kesulitan, jumlah soal, dan kisi-kisi soal yang sama pada materi kubus dan balok.

Populasi dalam penelitian ini adalah siswa kelas $\mathrm{VIII}^{\mathrm{A}}$, VIII ${ }^{\mathrm{B}}$, $\mathrm{VIII}^{\mathrm{C}}$, $\mathrm{VIII}^{\mathrm{D}}$ dan $\mathrm{VIII}^{\mathrm{E}}$ semester genap SMP Negeri 1 Sukoharjo tahun pelajaran 20152016. Pengambilan sampel menggunakan teknik cluster random sampling, sehubungan dengan populasi penelitian berbentuk kelompok yang terdiri dari 8 kelas dan setiap kelas mempunyai karakteristik yang sama. Maka penentuan sampel dengan cara undian yaitu dengan menuliskan kedelapan kelas pada masing-masing kertas lalu kertas digulung dan dikocok. Sehingga terpilih 
kelas VIII $^{\mathrm{B}}$ sebagai sampel 1 dan kelas VIII ${ }^{\mathrm{A}}$ sebagai sampel 2.

\section{Instrumen Penelitian}

Data hasil belajar matematika pada materi kubus dan balok merupakan nilai yang didapat melalui tes tertulis setelah pembelajaran. Perhitungan penilaian per soal dengan cara :

$\frac{\text { Skor perolehan peserta didik }}{\text { Skor maksimum tiap butir soal }} \times$ Bobot soal

Selanjutnya, semua nilai dijumlahkan yang diperoleh dari semua soal. Jumlah nilai ini disebut nilai akhir dari suatu perangkat tes yang diberikan. (Arifin, 2012:128).

\section{Pengembangan Instrumen Penilaian}

\section{1) Analisis Hasil Uji Coba Instrumen}

\section{a) Validitas}

Validitas isi dilakukan dengan cara mencocokkan butir-butir tes dengan indikator yang ada. Dari hasil analisis diperoleh bahwa butir-butir tes yang digunakan sesuai dengan indikator dan telah memenuhi tujuan pembelajaran. Maka dari itu, dilihat dari isinya soalsoal tes tersebut dapat dikatakan sebagai alat ukur yang valid. Selain validitas isi digunakan pula validitas tes tiap item instrumen yakni menggunakan analisis faktor yaitu dengan mengkorelasikan antara skor item instrumen dengan rumus Pearson Product Moment yaitu :

$$
r_{h t g}=\frac{n\left(\sum X Y\right)-\left(\sum X\right)\left(\sum Y\right)}{\sqrt{\left[n \sum X^{2}-\left(\sum X\right)^{2}\right]\left[n \sum Y^{2}-\left(\sum Y\right)^{2}\right]}}
$$

\section{Dimana:}

$r_{\text {hitung }}:$ koefisien korelasi

$\sum X_{i} \quad$ : jumlah skor item

$\sum Y$ : jumlah skor total (seluruh item)

n : jumlah responden

(Riduwan, 2010:98)

Selanjutnya dihitung dengan Uji-t dengan rumus

$$
t_{\text {hitung }}=\frac{r \sqrt{n-2}}{\sqrt{1-r^{2}}}
$$

Dimana :

t $\quad$ : Nilai t hitung

$\mathrm{r} \quad$ : Koefisien korelasi hasil $\mathrm{r}$ hitung

n : Jumlah responden

Distribusi ( tabel t ) untuk $\alpha=0,05$ dan derajat kebebasan $(\mathrm{dk}=\mathrm{n}-2)$.

Kaidah keputusan :

Jika $\quad t_{\text {hitung }} \geq t_{\text {tabel }}$ berarti valid $t_{\text {hitung }}<t_{\text {tabel }}$ berarti tidak valid. Setelah dilakukan uji validitas dengan menggunakan uji-t, maka akan diketahui valid atau tidaknya instrumen tersebut sebagai suatu alat ukur. Jika dari hasil uji validitas diketahui bahwa instrumen tersebut valid, maka harus dilihat kriteria penafsiran mengenai indeks korelasinya (r). Hal ini dilakukan untuk mengetahui tingkat validitas dari instrumen tersebut. 
b) Reliabilitas Tes

Reliabilitas tes dihitung menggunakan rumus alpha yaitu:

$$
r_{11}=\left(\frac{k}{k-1}\right)\left(1-\frac{\sum S_{i}}{S_{t}}\right)
$$

Untuk mengetahui ada tidaknya perbedaan rata-rata hasil belajar siswa pada materi kubus dan balok antara yang pembelajarannya menerapkan model pembelajaran kooperatif mind mapping dengan yang pembelajarannya menerapkan model pembelajaran kooperatif mind mapping berbasis media audio visual, digunakan statistik parametris yaitu uji-t. Sebelum uji-t dilakukan, dua asumsi dasar yang harus dipenuhi adalah uji normalitas dan uji homogenitas.

\section{2) Analisis Data Hasil Penelitian}

Hasil analisis data melalui beberapa tahap, yaitu :

1. Uji normalitas data Dilakukan pada sampel 1 dan sampel 2. Uji normalitas data dilakukan mengetahui apakah data yang diperoleh berdistribusi normal atau tidak maka diadakan uji normalitas dengan menggunakan rumus chi kuadrat.

2. Uji homogenitas dilakukan untuk menguji apakah kedua sampel mempunyai varians yang sama atau tidak. Pengujian homogenitas varians digunakan uji $\mathrm{F}$.

3. Uji-t

Uji-t dilakukan untuk mengetahui ada tidaknya perbedaan rata-rata hasil belajar siswa pada materi kubus dan balok antara yang pembelajarannya menerapkan model pembelajaran kooperatif mind mapping dengan pembelajaran yang menerapkan model pembelajaran kooperatif mind mapping berbasis media audio visual.

\section{PEMBAHASAN}

Setelah melakukan analisis dengan melakukan uji normalitas data pada sampel 1 diperoleh $\chi_{\text {hitung }}^{2}=3,29$ dengan taraf nyata $5 \%$ ditemukan $\chi_{\text {tabel }}^{2}=11,070$ atau dapat dituliskan $\chi_{\text {hitung }}^{2}<\chi_{\text {tabel }}^{2}$. Dari kriteria uji yang ada diputuskan terima Ho dan tolak $\mathrm{H}_{1}$, yang menunjukkan bahwa data pada sampel 1 berdistribusi normal. Demikian pula pada data sampel 2, dari perhitungan diperoleh $\quad \chi_{\text {hitung }}^{2}=9,76$ dengan taraf nyata $5 \%$ ditemukan $\chi_{\text {tabel }}^{2}=$ 11,070 sehingga $\chi_{\text {hitung }}^{2}<\chi_{\text {tabel }}^{2}$ mengakibatkan terima Ho dan tolak $\mathrm{H}_{1}$, yang menunjukkan bahwa data pada sampel 2 berdistribusi normal. Dari kedua hasil analisis ini dapat disimpulkan bahwa data berasal dari sampel yang distribusi normal. Setelah diketahui bahwa data berasal dari 
distribusi normal, maka dilanjutkan dengan pengujian homogenitas. Dari perhitungan didapat $F_{\text {hitung }}=1,33$ dan dengan taraf nyata $5 \%$ ditemukan $F_{\text {tabel }}=1,77$ sehingga $F_{\text {hitung }}<F_{\text {tabel }}$ menyebabkan keputusan terima Ho dan tolak $\mathrm{H}_{1}$ yang menunjukkan varian kedua sampel homogen.

Berdasarkan kedua uji prasyarat yang telah dilakukan, diperoleh kesimpulan bahwa seluruh data berdistribusi normal dan homogen. Sehingga data telah memenuhi syarat untuk dilanjutkan dengan pengujian hipotesis yang menggunakan ujit. Dari analisis uji-t dua pihak dengan taraf nyata $5 \%$ yang telah dilakukan, didapatkan bahwa $t_{\text {hitung }}=5,31$ dan $t_{\text {tabel }}=1,995$. Berdasarkan kriteria uji jika $t_{\text {hitung }}>$ $t_{\text {tabel }}$ maka tolak Ho dan terima $\mathrm{H}_{1}$ yang berarti ada perbedaan rata-rata hasil belajar matematika siswa pada materi kubus dan balok yang pembelajarannya menerapkan model pembelajaran kooperatif mind mapping berbasis media audio visual dan tanpa media audio visual. Sedangkan dari analisis data uji-t satu pihak diperoleh $t_{\text {hitung }}=5,31$ dan dengan taraf nyata $5 \%$ ditemukan $t_{\text {tabel }}=1,67$. Berdasarkan kriteria uji jika $t_{\text {hitung }}>t_{\text {tabel }}$ maka tolak Ho dan terima $\mathrm{H}_{1}$ yang berarti ratarata hasil belajar matematika siswa pada materi kubus dan balok yang pembelajarannya menerapkan model pembelajaran kooperatif mind mapping berbasis media audio visual lebih besar daripada rata-rata hasil belajar matematika siswa yang pembelajarannya menerapkan model pembelajaran kooperatif mind mapping. Hal ini terlihat dari perolehan rata-rata hasil belajar matematika siswa yang menggunakan model pembelajaran kooperatif mind mapping berbasis media audio visual sebesar 78,68 dan rata-rata hasil belajar matematika siswa yang menggunakan model pembelajaran kooperatif mind mapping sebesar 64,61 dan selisih rata-rata antara keduanya adalah 14,07

\section{SIMPULAN}

Berdasarkan hasil analisis data dan uji hipotesis dalam penelitian ini, maka dapat diambil kesimpulan bahwa: 1) Ada perbedaan rata-rata hasil belajar matematika siswa pada materi kubus dan balok yang pembelajarannya menerapkan model pembelajaran kooperatif mind mapping berbasis media audio visual yaitu 5,31dan tanpa media audio visual yaitu sebesar 1,995 2) Rata-rata hasil belajar matematika siswa pada materi kubus dan balok yang pembelajarannya menerapkan model pembelajaran kooperatif mind mapping berbasis media audio visual lebih besar yaitu 5,31 dari pada rata-rata hasil belajar matematika siswa yang pembelajarannya menerapkan model pembelajaran kooperatif 
mind mapping yaitu 1,67. Dari hasil tersebut maka pembelajarn kooperatif mind mapping berbasis media audio visual lebih baik jika diterapkan dalam menyampaikan materi kubus dan balok.

Hal ini disebabkan karena model pembelajaran kooperatif mind mapping berbasis media audio visual yang diterapkan pada sampel 1 memberikan kesempatan kepada siswa untuk dapat lebih aktif dan siswa menjadi lebih termotivasi dalam proses pembelajaran yang memancing siswa menjadi lebih imajinatif serta kreatif dalam mengembangkan potensi kerja otak dan pola pikir nya sehingga siswa dapat berpikir aktif, kritis, penuh ide, dan mudah mengatur serta mengingat segala bentuk informasi yang disampaikan oleh guru. Penggunaan media audio visual membuat pembelajaran lebih efektif untuk menyampaikan materi tanpa membutuhkan banyak waktu bagi guru untuk mencatat dan menuliskan materi di papan tulis, sehingga dapat memberikan pengaruh yang positif terhadap keberhasilan pembelajaran dan dapat meningkatkan hasil belajar siswa. Hal ini sesuai dengan pendapat Collins et al (dalam Asyhar, 2012:19) menyatakan bahwa "penggunaan media ... video berpengaruh terhadap hasil belajar peserta didik".

\section{DAFTAR PUSTAKA}

Asyhar, H.R. 2012. Kreatif Mengembangkan Media Pembelajaran. Jakarta: Referensi Jakarta

Buzan, Tony. 2012. Buku Pintar Mind Map. Jakarta: Gramedia Pustaka Utama.

Kreativitas, M., Dalam, S., \& Ekonomi, P. (2015). Prosiding Seminar Nasional 9 Mei 2015 Metode Pembelajaran Mind mapping Sebagai Upaya Mengembangkan Kreativitas Siswa Dalam Pembelajaran Ekonomi, 108-117.

Murtiyasa, B. (n.d.). Pemanfaatan teknologi informasi dan komunikasi untuk meningkatkan kualitas pembelajaran matematika, 1-19.

Sanjaya, Wina. 2010. Strategi Pembelajaran Berorientasi Standar Proses Pendidikan. Jakarta: Kencana Prenada Media Group. 